\title{
Phenotypic spectrum of fetal Smith-Lemli-Opitz syndrome
}

Chloé Quélin (1)*, Philippe Loget (2), Alain Verloes (3), Anne Bazin (4), Bettina Bessières (5), Annie Laquerrière (6), Sophie Patrier (6), Romulus Grigorescu (7), Ferechté Encha-Razavi (5), Sophie Delahaye (8), Jean-Marie Jouannic (8), Bruno Carbonne (9), Dominique D’Hervé (10), Marie-Cécile Aubry (11), Guillaume Macé (9), Thierry Harvey (12), Yves Ville (13), Geraldine Viot (14), Nicole Joyé (7), Sylvie Odent $(1,15)$, Tania Attié-Bitach (16), Claude Wolf (17), Françoise Chevy (17), Pascale Benlian (18), Marie Gonzales (7)

(1) Clinical Genetics Unit, Rennes Sud University Hospital, Rennes, France

(2) Pathology Laboratory, Rennes Pontchaillou University Hospital, Rennes , France

(3) Department of Genetics and INSERM U676, Assistance Publique Hôpitaux de Paris (AP-HP), Robert DEBRE University Hospital, Paris, France

(4) Genetic Department, Cerba Laboratory, Saint Ouen L'Aumone, France

(5) Cytogenetic and Embryology Unit, APHP-Necker-Enfants Malades University Hospital, Paris, France

(6) Pathology Laboratory, Charles Nicolle University Hospital, Rouen, France

(7) Medical Genetic and Embryology Unit, APHP-Trousseau University Hospital, Paris, France

(8) Department of Obstetrics and Gynecology, APHP-Trousseau University Hospital, Paris, France

(9) Department of Obstetrics and Gynecology, APHP-Saint-Antoine University Hospital, Paris, France

(10) Clinique Mutualiste La Sagesse, Rennes, France

(11) Department of Obstetrics and Gynecology, APHP Cochin-Port-Royal, Paris, France

(12) Diaconnesses Hospital, Paris, France

(13) Department of Obstetrics and Gynecology, APHP-Necker-Enfants Malades University Hospital, Paris, France

(14) Department of Genetics, APHP Cochin-Port-Royal, Paris, France

(15) UMR 6061 CNRS, Faculty of medicine, Rennes, France, France

(16) Department of Genetics, APHP-Necker-Enfants Malades University Hospital, Paris, France

(17) ERL INSERM U1057- UMR 7203-UPMC. University of Paris 6, Paris, France

(18) U4M, Biochemistry and Molecular Biology, Lille University Hospital, Lille, France 
* Corresponding author's information

Dr Chloé Quélin

Génétique Clinique

Hôpital SUD 16, Bd de Bulqarie BP 9034735203 Rennes cedex 2 FRANCE

Tel:00 $33 \underline{299266744}$

Fax:00 $33 \underline{299266745}$

Email: Chloe.QUELIN@chu-rennes.fr 


\begin{abstract}
The Smith-Lemli-Opitz syndrome (SLOS) is an autosomal recessive multiple congenital malformation syndrome caused by dehydrocholesterol reductase deficiency. The diagnosis is confirmed by high 7and secondarily 8-dehydrocholesterol levels in plasma and tissues and/or by detection of biallelic mutations in the DHCR7 gene. The phenotypic spectrum of SLOS is broad, ranging from a mild phenotype combining subtle physical anomalies with behavioral and learning problems, to a perinatally lethal multiple malformations syndrome. The fetal phenotype of SLOS has been poorly described in the literature. We report a series of 10 fetuses with molecularly proven SLOS. Even in young fetuses, the facial dysmorphism appears characteristic. Genital abnormalities are rare in $46, X X$ subjects. Gonadal differentiation appears histologically normal and in agreement with the chromosomal sex, contrary to what has been previously stated. We observed some previously unreported anomalies: ulnar hypoplasia, vertebral segmentation anomalies, congenital pulmonary adenomatoid malformation, fused lungs, laparoschisis, holomyelia and hypothalamic hamartoma. This latter malformation proves that SLOS phenotypically overlaps with Pallister-Hall syndrome which remains clinically a major differential diagnosis of SLOS.
\end{abstract}




\section{Introduction}

Smith-Lemli-Opitz syndrome (SLOS, MIM270400) is an autosomal recessive multiple congenital malformation syndrome with growth failure and mental retardation, first delineated in 1964. SLOS results from reduced activity of 7-dehydrocholesterol reductase, the final enzyme of the cholesterol biosynthesis pathway \{Porter, $2011 \# 28\}$ that converts 7-dehydrocholesterol to cholesterol. SLOS diagnosis can be confirmed by demonstrating, by gas chromatography-mass spectrometry (GC-MS), elevated precursor sterols, mainly 7- and 8-dehydrocholesterol in plasma and tissues, sometimes with low plasma cholesterol levels. In 1998, mutations in the DHCR7 gene were shown to cause SLOS. Over 130 different mutations have now been identified in SLOS patients (detection rate 96\%), among which the common, recurrent mutation IVS8-1G>C and two frequent mutations in Poland (W151X and V326L). The incidence of SLOS has been estimated to be 1/20 000$1 / 70000$ but is strikingly different among various ethnic groups. The frequency of heterozygote is estimated as 3 to $4 \%$ in the Caucasian populations, a value that seems incompatible with the low reported incidence.

The phenotypic spectrum of SLOS is very broad, ranging from mild minor physical anomalies with behavioral and learning problems to a prenatally or perinatally lethal multiple congenital anomaly (MCA) syndrome. Post-natal clinical findings in molecularly proven SLOS and their frequency have been reported by Kelley et al. and by Goldenberg et al. , but the fetal phenotype has rarely be addressed. Goldenberg et al. briefly described 12 fetuses among a series of 45 SLOS. The same authors reviewed ultrasound findings in a series of 30 biochemically confirmed SLO cases : nuchal edema (during the first trimester of pregnancy), renal, cardiac or cerebral anomalies, ambiguous genitalia or a 46,XY karyotype in a phenotypically female fetus and polydactyly were the most common findings. Only two other biochemically confirmed fetal cases have been reported .

Prenatal diagnosis of SLOS can be essentially done either by sterols profiling in amniotic fluid or chorionic villi, or by DHCR7 molecular analysis. Moreover maternal urine or serum steroid measurements by GC-MS (pregnanetriol, 7-dehydropregnanetriol, 8-dehydropregnanetriol, oestriol and 8-dehydroesteriol) should be a reliable non-invasive technique between 14 and 22 weeks' gestation . Antenatal diagnosis of SLOS is often made following familial history or ultrasound findings (mainly growth retardation with genital abnormalities). A better knowledge of the fetal phenotype of SLOS could help the practitioners of fetal medicine units to diagnose more accurately SLOS during pregnancy. 
We report here the phenotype of 10 fetal SLOS confirmed by biochemical assays and molecular studies.

\section{Materials and Methods}

The series was build retrospectively through a conjoint effort of the members of the French fetal pathology society (SOFFOET). We collected data on 10 fetuses with Smith-Lemli-Opitz syndrome (born between 1999 and 2010). Termination of pregnancy (TOP) was performed in accordance with the French legislation and was followed by fetopathologic examination. The gestational age at which TOP was performed varied from 16 weeks of gestation (GW) to $34 \mathrm{GW}$. There was $546, \mathrm{XX}$ and 5 $46, \mathrm{XY}$ fetuses. None of them was born to consanguineous parents and there was no positive family history of SLOS.

In accordance with the French bioethic laws, written signed consent was obtained from (at least) the mother for pathological examination and for genetic investigations. Standard fetal examination included photographs, evaluation of the fetal biometrics, $\mathrm{X}$ ray survey, external examination, autopsy and examination of placenta. All viscera, including the brain, were dissected, weighed and stained with hematoxylin-eosin (H\&E) for histologic analysis. Fetal and/or placental tissue samples were frozen for biochemical analysis and DNA extraction.

Diagnosis of SLOS were suspected on fetal phenotype at prenatal ultrasound scan (USS) for cases 2 and 7 or at fetopathologic examination, and no other diagnostics tests has been performed, except GLI3 sequencing in case 6 (see below). Elevated 7-dehydrocholesterol and 8-dehydrocholesterol were assayed in liver tissue, lung tissue or fetal blood, using GC-MS. Molecular analysis of the DHCR7 gene was performed using standard molecular procedures. Segregation of the variants was confirmed by studying parental DNA.

\section{Results}

\section{Prenatally detected anomalies (Table 1 )}

At prenatal USS, four fetuses (on eight) showed increased nuchal translucency. The main USS anomalies were intrauterine growth retardation (IUGR) with oligo- or anhydramnios in seven cases, congenital heart defects, limb defects (mainly postaxial polydactyly), cerebral and renal anomalies. One fetus had only IUGR associated with pulmonary valvular dysplasia. 


\section{Fetal pathology (Tables 1 and 2)}

Seven fetuses showed IUGR and two were between the $10^{\text {th }}$ and the $25^{\text {th }}$ centile. Most showed micromelia with short long bones. Facial dysmorphism was noted in all fetuses, mainly short nose with anteverted nares (Fig. 1). Cleft palate or bifid uvula was seen in 4 fetuses. All fetuses had some limb defects: syndactyly of toes II-III, postaxial polydactyly of hands and feet, short and proximally placed thumbs and deep distal palmar crease between the second and third fingers, giving sometimes a "split hand like" appearance (Fig. 2). All female fetuses had normal external genitalia, and all male fetuses had ambiguous genitalia (Fig. 3). One fetus (case 5) had bicornuate uterus bicollis (Fig. 4A). Microscopic examination of the gonads disclosed normal ovaries in all 46, XX fetuses and testes in all 46,XY fetuses, without histologic evidence of gonadal dysgenesis. Most fetuses $(8 / 10)$ had abnormal lung segmentation and renal hypoplasia or agenesis $(8 / 10)$. One fetus only had a normal heart. One fetus had anomalous pulmonary venous return. 3 fetuses had common mesentery. Two fetuses had polysplenia and two had enlarged pancreatic tail. Radiologic anomalies included shortened long bones and brachymesophanlangy of fingers II (Fig.5). Four fetuses had cerebral biometries on the $5^{\text {th }}$ centile, and five had true microcephaly. Holoprosencephaly was present in one case. Anomalies not reported before in SLOS included congenital pulmonary adenomatoid malformation, fused lungs, laparoschisis (Fig 4A), hypothalamic hamartoma and holomyelia (Fig. 4B), vertebral segmentation defects and ulnar hypoplasia (Fig. 5).

\section{Metabolic and genetic screening}

The clinical diagnosis of SLO syndrome was confirmed by high levels of 7-dehydrocholesterol and 8dehydrocholesterol in liver, lung or fetal blood in all cases but case 8 (Table 3). For case 7, the diagnosis was confirmed by prenatal sterol measurement performed on amniotic fluid (cholesterol $0.03 \mathrm{~g} / \mathrm{l}, 7-\mathrm{DHC} 0.023 \mathrm{~g} / \mathrm{l}$ and 8-DHC $0.017 \mathrm{~g} / \mathrm{l})$. Molecular analysis of the DHCR7 gene showed compound heterozygote mutations in 7 cases and homozygote mutations in 3 cases (Table 3 ). In fetus 5, 3 mutations were identified in the $D H C R 7$ gene, two of which in exon 4 inherited from the father (c.208G $>\mathrm{T}$ and $c .149 \mathrm{C}>\mathrm{T}$ ) and the third mutation inherited from the mother. Because of the existence of a hypothalamic hamartoma in case 6, a coincident mutation of GLI3 was excluded by direct sequencing.

\section{Discussion}

Several differences exist between our prenatal series and the postnatal ones : renal anomalies (mainly hypoplasia) are reported in all cases of this series, versus $40 \%$; pulmonary segmentation defects are present in 9/10 fetuses of our study, versus $17 \%-45 \%$; incidence of intestinal malrotation was $6 \%$ in a previous series, but affected $60 \%$ of the fetuses of this study; and finally brain 
malformations are also more frequent in our study. Obviously, fetopathologists can describe anomalies which are less accessible to pediatric examination. To the contrary, some typical findings of SLOS, as cataracts or colonic aganglionosis, are difficult to assess histologically and can be missed antenatally. Incidence of others malformations, such as $\operatorname{limb}$ anomalies, is in agreement with the literature, except for absent or hypoplastic middle phalanx of the second finger that seems more frequent than previously suspected. Lin et al. reported five major types of heart defects: atrioventricular canal, atrial septal defect ostium secundum type, patent ductus arteriosus, abnormal pulmonary venous return (APVR) and ventricular septal defects. In this series, nine fetuses have cardiac defects, mostly atrioventricular canal. Facial dysmorphism is present even in midtrimester fetuses: bitemporal narrowing, hypertelorism, short nose with anteverted nares, microretrognathia, large mouth, low set and posteriorly rotated ears and short neck. In case 5, these anomalies are blurred out by holoprosencephaly, a malformation which has been reported previously in nine SLOS patients. All male fetuses have external genital anomalies ranging from bifid scrotum to apparently female appearance. To the contrary, the female fetuses of this series have no anomalies of the external genitalia. Case 5 has bicornuate uterus, a rare but already described malformation. We observed normal gonadal differentiation in all our XY fetuses, irrespective of the level of external ambiguity. Referring to an article published in 1974, when biochimical diagnosis of SLOS was not possible, Kelley et al. stated that gonads varies from normal testes to ovotestis and to normal ovaries, or may be missing. No publication has addressed this issue since the discovery of the metabolic anomaly of SLOS, and gonadal differentiation was not described in two recent fetal cases . We suspect that the 1974 paper was based on a syndromologically heterogeneous collection. Indeed, our observation is not surprising, considering the fact that gonadal differentiation is not influenced by gonadal steroids. Our series confirms the retrospective data of Goldenberg on prenatal USS signs . All fetuses but one have IUGR of variable severity. Microcephaly is the most common sign during the $2^{\text {nd }}$ and $3^{\text {rd }}$ trimester of pregnancy. Case 9 has normal growth parameters at $16 \mathrm{GW}$, but growth retardation may not be present as early. For case 1, IUGR was the major antenatal sign. Non-vascular IUGR should prompt the sonographer to consider SLOS, especially when karyotype is $46, X X$. Two fetuses in our series were diagnosed early in the second trimester (fetus 9 and 10). Our study shows for the first time that early fetal phenotype of SLOS is recognizable and very similar to the phenotype of elder children. Indeed facial dysmorphism, already present, was felt to be a good handle to elicit the diagnosis in a MCA fetus. These two cases illustrate the high interest of pathological fetal examination even for young MCA fetuses who should therefore not be terminated by surgical aspiration to allow a complete fetal examination. 
We observed atypical manifestations of SLOS. Many skeletal malformations have been reported in SLOS, as polydactyly, metacarpal/tarsal hypoplasia, syndactyly, disproportionate short limbs, chondrodysplasia punctata, ribs anomalies, scoliosis, kyphosis or high ovoid lumbar vertebral bodies. A single patient suspect of SLOS was reported with ectrodactyly, radial aplasia and monodactyly. We now definitively add ulnar hypoplasia (patient 3 ) and vertebral segmentation anomalies (patient 3 ) to this list. Five fetuses also have a deep distal palmar crease with widely separate the second and third fingers, giving a "split hand like" appearance (Fig. 2). Abnormal pulmonary development has already been reported in SLOS. We can add congenital pulmonary adenomatoid malformation and fused lungs (Fig. 4A) to the list. The laparoschisis observed in case 4 may be fortuitous, but could mislead the clinician. Fetus 8 (previously been reported by Marcorelles and Laquerriere ) has holomyelia, which is a partial or complete fusion of both anterior horns of the spinal cord. Distal arthrogryposis may be the result of this developmental anomaly. The presence of a hypothalamic hamartoma in fetus 6 makes SLOS overlap with Pallister-Hall syndrome (PHS, MIM146510), ascribed to GLI3 mutations. Hypothalamic hamartoma, short limbs, postaxial or central polydactyly (with $\mathrm{Y}$ shaped central metacarpal or tarsal) and dysplastic nails, bifid epiglottis or laryngotracheal cleft, imperforate anus and other visceral malformations (renal abnormalities, genitourinary anomalies or abnormal lung segmentation) are the hallmarks of PHS. Similarities between both syndromes have been stressed, but hypothalamic hamartoblastoma has never been formally reported with SLOS. When both diseases where still unexplained, Donnai et al. even suggested that the Pallister-Hall syndrome and severe Smith-Lemli-Opitz syndrome may represent phenotypic variations of one condition . Indeed, some ancient cases may have been misdiagnosed on clinical ground in the past. Verloes et al. suggested that patient 6 from the seminal report of PHS, who had an hamartoma, flat nose, low-set and posteriorly rotated ears, micrognathia, left postaxial polydactyly, bilateral $2 / 3$ toes syndactyly, bilateral cataracts and Hirschprung disease, had SLOS and not PHS. Interestingly, this phenotypic overlap with PHS and the possible holoprosencephaly/midline defects observed in SLOS suggest a defect in SHH pathway in SLOS mutated patients. Indeed, SHH protein precursor undergoes autocatalytic internal cleavage mediated by covalently attached cholesterol to the $\mathrm{N}$-terminal signaling domain, and the potential effects of perturbed cholesterol biosynthesis on embryonic signaling proteins has already been discussed in SLOS. Distinction between these two syndromes is of obvious significance for genetic counseling, as Pallister-Hall syndrome is an autosomal dominant disorder (mainly sporadic cases resulting from de novo GLI3 mutations), whereas SLOS is recessively inherited. We report for the first time systematic histologic examination of SLOS placenta. This organ has grossly normal architecture, but three fetuses show 
placental hypotrophy. It will be of interest to better study placentas of SLOS in order to confirm and precise these anomalies.

There is an apparent discordance between the low incidence of SLOS as compared to the estimate carrier frequency . Jezela-Stanek et al. established the prospective incidence of SLOS in Poland in order to compare it to a previous carrier frequency estimation, but doesn't resolve this discrepancy between the predicted and observed incidence. No segregation of SLOS has been published. The "missing SLOS" may correspond to the two tails of the clinical spectrum: SLOS may remain undiagnosed among mildly affected individuals who do not show the key features that would trigger cholesterol analysis, and severe cases may stay hidden among early miscarriages. In accordance with this hypothesis, 4 couples suffered multiple early spontaneous abortions ( 2 for case 6, 5 for case 8,5 for case 9 and 1 for case 10). For case 1, pregnancy obtained by in vitro fertilization was initially gemellar bichorionic biamniotic and reduced spontaneously. For case 6, the fourth pregnancy ended at $6 \mathrm{GW}$ and the sterols analysis by GC-MS in miscarriage product (case $6^{\prime}$ ) showed high levels of 7- and 8-dehydrocholesterol, confirming recurrence (Table 3). Moreover, three fetuses had increased nuchal translucency in the first trimester of pregnancy. As Maymon et al., we could speculate, that some of fetal loss associated with SLOS may be related to nuchal oedema and subsequent fetal hydrops, reflecting the severity of the phenotype in these families. SLOS could be an unsuspected cause of recurrent early spontaneous abortions without identified cause, but systematic screening of $D H C R 7$ In couples with recurrent miscarriages has never been carried on.

All the fetuses, who can be considered as severe (prenatally detected), were genotyped and found to be either homozygous or compound heterozygous, with at least one null allele. Our observation confirms that severe phenotypes are mainly associated with nonsense and splice-site mutations (null alleles), although strict genotype-phenotype correlations are difficult and significant variation is seen in severity even among individuals with similar mutations, suggesting influences of other factors on the phenotype. Fetus 5 with holoprosencephaly has 3 deleterious mutations, which could partly explain the severity of the phenotype. The efficiency of cholesterol transport from the mother to the fetus early in pregnancy may be one of these factors. For example, Apolipoprotein $E$ protein is a major component of the cholesterol transport system in humans and studies suggest that the maternal apolipoprotein E genotype (ApoE) was implicated in phenotype heterogeneity, the maternal apo epsilon2 genotype (APOE2 protein) being associated with a severe Smith-Lemli-Opitz syndrome phenotype. Another hypothesis might be modifier alleles of genes belonging to the SHH signaling pathway. 
In summary, we report 10 fetuses with SLOS, illustrating the broad clinical variability in the severe end of spectrum of this disorder and question the potential role of DHCR7 deficiency in early abortion. We illustrate the usefulness of systematic feto-placental examination in syndromes which are not universally lethal: several anomalies that we describe would probably never have been reported in pediatric series, as morphologically-oriented autopsies are rarely performed in elder children, and as feto-placental examination allows exhaustive description of anomalies which are not easily accessible by clinical inspection or ex vivo imaging.

Acknowledgements: The authors are indebted to Drs Antoinette Gelot, Catherine Fallet-Bianco, Catherine Fredouille, Lucile Houyel, Laurent Fermont for their useful comments 


\section{Tables}

Table 1: Prenatally detected anomalies and external phenotypic description of the 10 fetuses with Smith-Lemli-Opitz syndrome

(AVC Atrioventricular Canal ; B Bilateral ; CCA Corpus Callosum Agenesis ; CLP Cleft Lip and Palate ; CH Crown-Heel lenght ; CIV Interventricular communication ; CRL: Crown-Rump Length ; GW: gestational weeks ; HLH Hypoplastic Left Heart ; L Left ; ND Not determined ; R Right ; SA Spontaneous Abortion; VH Vertex-Heel length)

\begin{tabular}{|c|c|c|c|c|c|c|c|c|c|c|}
\hline & Case 1 & Case 2 & Case 3 & Case 4 & Case 5 & Case 6 & Case 7 & Case 8 & Case 9 & Case 10 \\
\hline Previous pregnancy & G1P1 & $\mathrm{G} 2 \mathrm{P} 2$ & G3P2 & $\mathrm{G} 2 \mathrm{P} 2$ & $\mathrm{G} 2 \mathrm{P} 2$ & G3P1 (2SA) & $\mathrm{G} 2 \mathrm{P} 2$ & G6P1 (5SA) & G6P1 (5SA) & G4P2 \\
\hline Gestational Age (GW) & 32 & 34 & 21 & 34 & 24 & 26 & 26 & 23 & 16 & 19 \\
\hline Karyotype & $46, X X$ & $46, X Y$ & $46, X Y$ & $46, X X$ & $46, X X$ & $46, X Y$ & $46, X Y$ & $46, X X$ & $46, X Y$ & $46, X X$ \\
\hline \multicolumn{11}{|l|}{ Fetal echocardiography } \\
\hline increased nuchal translucency & - & - & + (value ND) & - & - & $\begin{array}{c}+(3,2 \mathrm{~mm} \text { for } \\
\text { CRL of } 49 \mathrm{~mm})\end{array}$ & ND & ND & $\begin{array}{c}+(5,2 \mathrm{~mm} \text { for } \\
\text { CRL of } \\
57 \mathrm{~mm})\end{array}$ & $\begin{array}{c}+(3 \mathrm{~mm} \text { for } \\
\text { CRL of } \\
58 \mathrm{~mm})\end{array}$ \\
\hline IUGR & + & short limbs & + & + & + & + & + & ND & - & + \\
\hline oligo/anamnios & - & - & + & + & - & - & ND & + & + & - \\
\hline extremities anomalies & - & $\begin{array}{c}\text { postaxial } \\
\text { polydactyly left } \\
\text { hand }\end{array}$ & $\begin{array}{l}\text { postaxial } \\
\text { polydactyly }\end{array}$ & - & - & $\begin{array}{c}\text { postaxial } \\
\text { polydactyly of } \\
\text { hands/irregular } \\
\text { toes }\end{array}$ & $\begin{array}{c}\text { polysyndactyly } \\
\text { of feet }\end{array}$ & - & - & hexadactyly? \\
\hline cardiopathy & $\begin{array}{l}\text { pulmonary } \\
\text { valvular } \\
\text { dysplasia }\end{array}$ & AVC & CIV? & - & AVC & partial AVC & AVC & AVC & $\begin{array}{l}\text { AVC, HLH, } \\
\text { mitral } \\
\text { hypoplasia }\end{array}$ & AVC \\
\hline microcephaly / brain anomalies & microcephaly & CCA & partial CCA? & microcephaly & $\mathrm{CC}$ anomalies & - & $\begin{array}{l}\text { microcephaly/ } \\
\text { gyration } \\
\text { retardation }\end{array}$ & CCA & - & - \\
\hline others anomalies & & $\begin{array}{c}\text { renal/lung } \\
\text { anomalies, sexual } \\
\text { ambiguity }\end{array}$ & & $\begin{array}{l}\text { laparoschisis/ } \\
\text { small kidneys }\end{array}$ & $\begin{array}{l}\text { bilateral cleft } \\
\text { lip and palate } \\
\text { and renal } \\
\text { anomalies }\end{array}$ & & retrognatism & $\begin{array}{l}\text { bilateral } \\
\text { renal } \\
\text { agenesis }\end{array}$ & $\begin{array}{l}\text { kidneys and } \\
\text { bladder not } \\
\text { seen }\end{array}$ & $\begin{array}{l}\text { stomach and } \\
\text { kidneys not } \\
\text { seen }\end{array}$ \\
\hline Weight(g) $/ \mathrm{CH}(\mathrm{cm}) /$ foot length $(\mathrm{cm})$ & $1128 / 37,5 / 5,6$ & $625 / 31,5 / 4,3$ & $250 / 21 / 3$ & $1896 / 43 / 6,8$ & $390 / 27,5 / 3,7$ & $677 / 31 / 4,6$ & $545 / 29,5 / 4,1$ & $337 / 23 / 3$ & $89 / 15 / 1,7$ & $130 / 18,5 / 2$ \\
\hline IUGR & + & 10-25th & + & 10-25th & + & + & + & + & - & + \\
\hline Microcephaly (centiles) / brain weight & + & 5 th $/ 87 \mathrm{~g}$ & 5 th $/ 40 \mathrm{~g}$ & $+/ 212 g$ & 5 th $/ 86,5 \mathrm{~g}$ & $+/ 91 \mathrm{~g}$ & 5th / ? & $+/ 54 \mathrm{~g}$ & $-/ 26 g$ & $+/ 19,5 \mathrm{~g}$ \\
\hline
\end{tabular}




\begin{tabular}{|c|c|c|c|c|c|c|c|c|c|c|}
\hline \multicolumn{11}{|l|}{ Facial dysmorphism } \\
\hline bitemporal narrowing & + & - & + & + & - & - & + & + & - & - \\
\hline hypertelorism & + & + & + & + & - & + & + & - & + & - \\
\hline anteverted nares/upturned & + & + & + & + & - & + & + & + & + & + \\
\hline microretrognathia & + & + & + & + & - & + & + & + & + & + \\
\hline smooth/convex philtrum & - & + & - & + & & + & + & + & + & + \\
\hline short philtrum & + & - & + & + & & & + & + & - & - \\
\hline low-set/posteriorly rotated ears & + & + & + & + & + & + & + & - & + & + \\
\hline short neck & + & + & + & + & + & + & + & + & + & + \\
\hline large mouth & - & - & + & - & + & + & + & + & & + \\
\hline midline cleft palate/bifid uvula & - & cleft palate & - & bifid uvula & bilateral CLP & - & - & - & - & cleft palate \\
\hline narrow palate & + & ND & - & - & & + & - & - & + & \\
\hline Micromelia & + & + & + & + & + & + & + & + & + & + \\
\hline \multicolumn{11}{|l|}{ Feet anomalies } \\
\hline Syndactyly of toes II-III & + & + & + & + & + & + & + & + & + & + \\
\hline short hallux & + & + & - & - & + & - & - & + & - & - \\
\hline post-axial polydactyly (L,R or B) & - & - & $+\mathrm{L}$ & - & - & $+\mathrm{B}$ & $+\mathrm{R}$ & $+\mathrm{R}$ & $+\mathrm{B}$ & - \\
\hline \multicolumn{11}{|l|}{ Hands anomalies } \\
\hline post-axial polydactyly (L,R or B) & - & $+\mathrm{L}$ & $+\mathrm{B}$ & - & - & $+\mathrm{B}$ & - & $+\mathrm{B}$ & $+\mathrm{B}$ & - \\
\hline short/proximally placed thumbs & + & + & + & + & + & - & - & - & + & + \\
\hline \multirow[t]{2}{*}{ extended distal palmar crease } & + & + & + & + & ND & - & + & - & ND & ND \\
\hline & - & $\begin{array}{l}\text { open urogenital } \\
\text { groove and } \\
\text { unfused genital } \\
\text { swelling }\end{array}$ & bifid scrotum & - & - & $\begin{array}{l}\text { external female } \\
\text { genitalia }\end{array}$ & $\begin{array}{l}\text { open urogenital } \\
\text { groove and } \\
\text { unfused genital } \\
\text { swelling }\end{array}$ & - & + & - \\
\hline
\end{tabular}


Table 2: Visceral and radiological anomalies of the 10 fetuses with Smith-Lemli-Opitz syndrome

(AVCD Atrioventricular ; APVR Anomalous Pulmonary Venous Return ; CCA Agenesis of the corpus callosum ; HLH Hypoplastic Left Heart ; HPE Holoprosencephaly ; N Normal ; NA: not available ; VSD Ventricular Septal Defect)

\begin{tabular}{|c|c|c|c|c|c|c|c|c|c|c|}
\hline & Case 1 & Case 2 & Case 3 & Case 4 & Case 5 & Case 6 & Case 7 & Case 8 & Case 9 & Case 10 \\
\hline Gonads & ovaries & testes & testes & ovaries & ovaries & testes & testes & ovaries & testis & ovaries \\
\hline Kidney & $\begin{array}{l}\text { sigmoid kidney / } \\
\text { hypoplasia }\end{array}$ & $\begin{array}{l}\text { Left pelvicaliceal } \\
\text { dilatation }\end{array}$ & $\begin{array}{c}\text { hypo/aplasia + } \\
\text { cysts }\end{array}$ & hypoplasia & hypoplasia & hypoplasia & hypoplasia & Bilat agenesis & $\begin{array}{c}\text { severe } \\
\text { hypoplasia }\end{array}$ & left pelvic kidney \\
\hline Cardiovascular & $\begin{array}{c}\text { pulmonary } \\
\text { valvular } \\
\text { dysplasia, short } \\
\text { ductus } \\
\text { arteriosus. }\end{array}$ & $\begin{array}{l}\text { AVC with riht } \\
\text { ventricular } \\
\text { hypoplasia }\end{array}$ & $\begin{array}{l}\text { HLH, arch aortic } \\
\text { tubular } \\
\text { hypoplasia and } \\
\text { subaortic VSD. }\end{array}$ & - & Partial AVCD & $\begin{array}{l}\text { Left cavities } \\
\text { hypoplasia, } \\
\text { partial AVCD } \\
\text { and APVR }\end{array}$ & AVC & AVC & $\begin{array}{c}A V C D \text { and mitral } \\
\text { atresia }\end{array}$ & AVC \\
\hline Lung & $\begin{array}{l}\text { Lobation } \\
\text { anomalies }\end{array}$ & $\begin{array}{c}\text { lobation } \\
\text { anomalies /cysts }\end{array}$ & hypoplasia & $\begin{array}{l}\text { lobation } \\
\text { anomalies }\end{array}$ & $\mathrm{N}$ & $\begin{array}{l}\text { absent lobation / } \\
\text { fused lungs }\end{array}$ & $\begin{array}{l}\text { lobation } \\
\text { anomalies / } \\
\text { hypoplasia }\end{array}$ & absent lobation & absent lobation & $\begin{array}{l}\text { lobation } \\
\text { anomalies }\end{array}$ \\
\hline CNS & ? & posterior CCA & $\begin{array}{l}\text { hypothalamic } \\
\text { and pallidum } \\
\text { dysgenesis and } \\
\text { cranial nerves } \\
\text { ganglia lesions }\end{array}$ & microcephaly & lobar HPE & $\begin{array}{l}\text { cerebellar and } \\
\text { brainstem } \\
\text { abnormalities / } \\
\text { Hypothalamic } \\
\text { hamartoma }\end{array}$ & NK & $\begin{array}{l}\text { CCA / rare } \\
\text { neuronal } \\
\text { heterotopia / } \\
\text { holomyelia }\end{array}$ & - & ACC \\
\hline Gastrointestinal & - & & $\begin{array}{l}\text { intestinal } \\
\text { malrotation }\end{array}$ & $\begin{array}{c}\text { laparoschisis / } \\
\text { common } \\
\text { mesentery }\end{array}$ & - & $\begin{array}{l}\text { Incomplete } \\
\text { common } \\
\text { mesentery }\end{array}$ & - & - & - & - \\
\hline Others & & $\begin{array}{l}\text { enlarged caudal } \\
\text { pancreas }\end{array}$ & & & $\begin{array}{l}\text { bicornuate } \\
\text { uterus bicolli }\end{array}$ & $\begin{array}{l}\text { enlarged caudal } \\
\text { pancreas }\end{array}$ & polysplenia & & $\begin{array}{c}\text { polysplenia } \\
\text { /single umbilical } \\
\text { artery }\end{array}$ & $\begin{array}{c}\text { single umbilical } \\
\text { arteryl } \\
\text { bicornuate uterus }\end{array}$ \\
\hline \multicolumn{11}{|l|}{ Skeletal } \\
\hline Short long bones & $+(F=49 \mathrm{~mm})$ & $+(F=35 \mathrm{~mm})$ & $\begin{array}{c}+ \text { Right ulnar } \\
\text { hypoplasia (F= } \\
\text { NK) }\end{array}$ & - $(F=62 \mathrm{~mm})$ & $+(\mathrm{F}=36 \mathrm{~mm})$ & $+(F=35 \mathrm{~mm})$ & $+(F=36 \mathrm{~mm})$ & $+(F=29 \mathrm{~mm})$ & $+(F=N K)$ & $+(F=N K)$ \\
\hline Brachymesophalangy of $2 \mathrm{~d}$ finger(s) & + & + & + & + & + & NK & NK & + & NK & + \\
\hline Placenta (weight) & $\begin{array}{c}\text { hypotrophy } \\
(229 \mathrm{~g} ; 5-10 \text { th } \\
325 \mathrm{~g}=\mathrm{M} 32)\end{array}$ & $\begin{array}{l}\mathrm{N}(235 \mathrm{~g} ; 75- \\
90 \mathrm{th})\end{array}$ & $N(94 \mathrm{~g} ;<10$ th $)$ & $\begin{array}{c}\mathrm{N}(417 \mathrm{~g} ; 50- \\
75 \mathrm{th})\end{array}$ & $\begin{array}{c}\text { hypotrophy } \\
(128 \mathrm{~g} ; 10 \text { th ; } \\
\text { 190g=M 24) }\end{array}$ & $\begin{array}{c}\mathrm{N}(240 \mathrm{~g} ; 50- \\
75 \mathrm{th})\end{array}$ & $\begin{array}{c}\text { hypotrophy } \\
(120 \mathrm{~g} ; 5-10 \text { th ; } \\
226 \mathrm{~g}=\mathrm{M} 26)\end{array}$ & $155 \mathrm{~g}$ & $\mathrm{~N}(69 \mathrm{~g} ; 25-50$ th $)$ & $\mathrm{N}(97 \mathrm{~g} ; 10-50$ th $)$ \\
\hline
\end{tabular}


Table 3: Biochemical and genetic data of the 10 fetuses with SLOS

\begin{tabular}{|c|c|c|c|c|c|c|}
\hline Cases & Tissus & $\begin{array}{c}\begin{array}{c}\text { Cholesterol } \\
(\mathrm{mg} / \mathrm{g})\end{array} \\
\end{array}$ & 7-DHC (mg/g) & 8-DHC (mg/g) & $7+8 \mathrm{DHC} / \mathrm{Chol}$ & Mutations ( 1 line per allele) \\
\hline 1 & Liver & 0,76 & 0,34 & 0,53 & 1,14 & $\begin{array}{l}\text { c.356del13nt (p.His119ProFsX23) } \\
\text { c.906C>G (p.Phe302Leu) }\end{array}$ \\
\hline 2 & Fetal blood & 113 mg/l & $77 \mathrm{mg} / \mathrm{l}$ & $299 \mathrm{mg} / \mathrm{l}$ & 3,33 & $\begin{array}{l}\text { c.1228G>A (p.Gly410Ser) } \\
\text { c.964-1 G>C (IVS8-1G>C) }\end{array}$ \\
\hline 3 & Lung & 0,22 & 1,57 & 1,91 & 15,82 & $\begin{array}{l}\text { c.438C>G (p.Asn146Lys) } \\
\text { IVS8-1G>C }\end{array}$ \\
\hline 4 & Liver & 1,6 & 0,05 & 0,08 & 0,08 & $\begin{array}{l}\text { c.506C>T (p.Ser169Leu) } \\
\text { IVS8-1G>C }\end{array}$ \\
\hline 5 & Lung & 0,41 & 1 & 0,99 & 4,85 & $\begin{array}{l}\text { c.149C }>T \text { (p.Ala50Val) } \\
\text { c.208G }>T \text { (p.Gly70Cys) } \\
\text { c.628A }>\text { T (p.Lys210X) } \\
\end{array}$ \\
\hline 6 & Liver & 0,21 & 0,6 & 1,14 & 8,29 & $\begin{array}{l}\text { IVS8-1G>C } \\
\text { IVS8-1G>C }\end{array}$ \\
\hline $\begin{array}{c}6^{\prime} \\
\text { (miscarriage) }\end{array}$ & Trophoblast & 2,22 & 0,372 & 0,088 & 0,21 & - \\
\hline 7 & Liver & 0,26 & 2,2 & 3,33 & 21,27 & $\begin{array}{l}\text { IVS8-1G>C } \\
\text { IVS8-1G>C }\end{array}$ \\
\hline 8 & & NA & NA & NA & NA & $\begin{array}{l}\text { IVS8-1G>C } \\
\text { c.452G>A (p.Trp151X) }\end{array}$ \\
\hline 9 & Liver & 0,18 & 0,55 & 1,69 & 12,44 & $\begin{array}{l}\text { IVS8-1G>C } \\
\text { c.682C }>\text { T (p.Arg228Trp) }\end{array}$ \\
\hline 10 & Liver & 0,104 & 0,21 & 0,224 & 4,17 & $\begin{array}{l}\text { IVS8-1G>C } \\
\text { IVS8-1G>C } \\
\end{array}$ \\
\hline Normal $(n=28)$ & Liver & $3.98 \pm 1.75$ & $0.003 \pm 0.003$ & $0.006 \pm 0.004$ & $0.002 \pm 0.002$ & \\
\hline
\end{tabular}


Table 4: Phenotypic overlap of SLO and Pallister-Hall syndromes

\begin{tabular}{|c|c|c|}
\hline & PHS & SLOS \\
\hline Gene & GLI3 & DHCR7 \\
\hline Inheritance pattern & Autosomal Dominant & Autosomal Recessive \\
\hline IUGR & +++ & + \\
\hline Renal & Hypoplasia/agenesis & hypoplasia \\
\hline Lund segmentation defects & + & + \\
\hline Cardiovascular defects & rare & + \\
\hline Imperforate anus & + & rare \\
\hline Hypothalamic hamartoma & + & rare \\
\hline $\begin{array}{c}\text { Epiglottic/laryngeal } \\
\text { abnormalities }\end{array}$ & + & - \\
\hline Extremities & $\begin{array}{l}\text { Post-axial and central } \\
\text { polydactyly, dysplastic nails, } \\
\text { brachytelephalangism }\end{array}$ & $\begin{array}{c}\text { Post-axial polydactyly and } 2 / 3 \\
\text { toe syndactyly }\end{array}$ \\
\hline Genital & $\begin{array}{c}\text { Rare (hydrometrocolpos, } \\
\text { vaginal atresia, urogenital } \\
\text { sinus, cloaca) }\end{array}$ & $+($ male $)$ \\
\hline Facial dysmorphism & $\begin{array}{c}\text { Downward slanting palpebral } \\
\text { fissures, short nose with } \\
\text { anteverted nares }\end{array}$ & $\begin{array}{c}\text { Bitemporal narrowing, } \\
\text { anteverted nares }\end{array}$ \\
\hline
\end{tabular}




\section{Legend to figures}

\section{Figure 1: Facial dysmorphism of fetuses 1 to 10}

(A) Profile pictures of fetuses 1 to 10 - (B) Frontal view of fetuses 1 to 8 . Note bitemporal narrowing, hypertelorism, short nose with anteverted nares, microretrognathia (severe for case 3), full cheeks, large mouth, low set and posteriorly rotated ears and short neck (figure numbering refers to the case numbers).

\section{Figure 2: Acral anomalies in fetal SLOS}

Note deep distal palmar crease between second and third fingers which have sometimes widely spaced ("split hand like") in cases 1, 2, 3, 4 and 7. Cases 2, 3, 6, 8 and 9 have postaxial hexadactyly. Case 8 has no palmar crease. Cases 8 and 10 have bilateral ulnar club hands. Thumbs are often short and proximally placed. Note some fetuses with camptodactyly and fifth finger clinodactyly. All fetuses except case 9 have bilateral syndactyly of toes II-III. Case 3 has syndactyly of toes II-III and IVV. Cases $3,6,7,8$ and 9 have unilateral or bilateral post-axial hexadactyly. Case 8 has fibular deviation of toes. Hallux are sometimes short and broad.

\section{Figure 3: Abnormal external genitalia in SLOS}

Cases 1 and 5 are female with normal external genitalia. Cases 2 and 7 have ambiguous genitalia with small genital tubercle, open urogenital groove and unfused genital swelling. Case 3 has bifid or incomplete fused scrotum. Case 6 is $46, X Y$ with phenotypically female appearance.

\section{Figure 4A: Unusual malformations in SLOS}

(a): congenital pulmonary adenomatoid malformation within the left upper lobe in fetus 2 - (b): absent pulmonary lobulation with posterior fused lungs in fetus $6-(c, d)$ : bicornuate uterus bicollis (e): laparoschisis . 
Figure 4B: CNS unusual malformations in SLOS

$(a, b)$ : hypothalamic hamartoma (arrow) in fetus 6 - (c): anterior spinal cord fusion (holomyelia) in fetus 8 (arrow).

Figure 5: Radiographic highlights in SLOS

(A): brachymesophanlangy of second finger in seven fetus - (B): associated right ulnar hypoplasia in case 3 - (C): vertebral segmentation defects (hemivertebra, agenesis of last sacral vertebra) in case 3. 


\section{References}

[1] M. Irons, E.R. Elias, G. Salen, G.S. Tint, A.K. Batta, Defective cholesterol biosynthesis in SmithLemli-Opitz syndrome, Lancet, 341 (1993) 1414.

[2] F.D. Porter, G.E. Herman, Malformation syndromes caused by disorders of cholesterol synthesis, J Lipid Res, 52 (2011) 6-34.

[3] C.A. Wassif, C. Maslen, S. Kachilele-Linjewile, D. Lin, L.M. Linck, W.E. Connor, R.D. Steiner, F.D. Porter, Mutations in the human sterol delta7-reductase gene at 11q12-13 cause Smith-Lemli-Opitz syndrome, Am J Hum Genet, 63 (1998) 55-62.

[4] B.U. Fitzky, M. Witsch-Baumgartner, M. Erdel, J.N. Lee, Y.K. Paik, H. Glossmann, G. Utermann, F.F. Moebius, Mutations in the Delta7-sterol reductase gene in patients with the Smith-Lemli-Opitz syndrome, Proc Natl Acad Sci U S A, 95 (1998) 8181-8186.

[5] A. Jezela-Stanek, E. Ciara, E. Malunowicz, K. Chrzanowska, A. Latos-Bielenska, M. KrajewskaWalasek, Differences between predicted and established diagnoses of Smith-Lemli-Opitz syndrome in the Polish population: underdiagnosis or loss of affected fetuses?, J Inherit Metab Dis, (2010).

[6] F.D. Porter, Smith-Lemli-Opitz syndrome: pathogenesis, diagnosis and management, Eur J Hum Genet, 16 (2008) 535-541.

[7] H. Yu, S.B. Patel, Recent insights into the Smith-Lemli-Opitz syndrome, Clin Genet, 68 (2005) 383391.

[8] M.J. Nowaczyk, J.S. Waye, J.D. Douketis, DHCR7 mutation carrier rates and prevalence of the RSH/Smith-Lemli-Opitz syndrome: where are the patients?, Am J Med Genet A, 140 (2006) 20572062.

[9] R.I. Kelley, R.C. Hennekam, The Smith-Lemli-Opitz syndrome, J Med Genet, 37 (2000) 321-335.

[10] A. Goldenberg, F. Chevy, C. Bernard, C. Wolf, V. Cormier-Daire, [Clinical characteristics and diagnosis of Smith-Lemli-Opitz syndrome and tentative phenotype-genotype correlation: report of 45 cases], Arch Pediatr, 10 (2003) 4-10.

[11] A. Goldenberg, C. Wolf, F. Chevy, A. Benachi, Y. Dumez, A. Munnich, V. Cormier-Daire, Antenatal manifestations of Smith-Lemli-Opitz (RSH) syndrome: a retrospective survey of 30 cases, Am J Med Genet A, 124A (2004) 423-426.

[12] F. Pelluard-Nehme, D. Carles, E.M. Alberti, R. Saura, C. Wong, C. Wolf, [Smith-Lemli-Opitz syndrome], Ann Pathol, 25 (2005) 318-321.

[13] J. Dubuisson, L. Guibaud, D. Combourieu, J. Massardier, D. Raudrant, [Utility of fetal ultrasonography in the prenatal diagnosis of Smith-Lemli-Opitz syndrome], Gynecol Obstet Fertil, 36 (2008) 525-528.

[14] J.S. Waye, B. Eng, M.J. Nowaczyk, Prenatal diagnosis of Smith-Lemli-Opitz syndrome (SLOS) by DHCR7 mutation analysis, Prenat Diagn, 27 (2007) 638-640.

[15] A. Jezela-Stanek, E.M. Malunowicz, E. Ciara, E. Popowska, B. Goryluk-Kozakiewicz, K. Spodar, M. Czerwiecka, J. Jezuita, M.J. Nowaczyk, M. Krajewska-Walasek, Maternal urinary steroid profiles in prenatal diagnosis of Smith-Lemli-Opitz syndrome: first patient series comparing biochemical and molecular studies, Clin Genet, 69 (2006) 77-85.

[16] C.H. Shackleton, J. Marcos, G.E. Palomaki, W.Y. Craig, R.I. Kelley, L.E. Kratz, J.E. Haddow, Dehydrosteroid measurements in maternal urine or serum for the prenatal diagnosis of Smith-LemliOpitz syndrome (SLOS), Am J Med Genet A, 143A (2007) 2129-2136.

[17] A.E. Lin, H.H. Ardinger, R.H. Ardinger, Jr., C. Cunniff, R.I. Kelley, Cardiovascular malformations in Smith-Lemli-Opitz syndrome, Am J Med Genet, 68 (1997) 270-278.

[18] D.D. Weaver, B.D. Solomon, K. Akin-Samson, R.I. Kelley, M. Muenke, Cyclopia (synophthalmia) in Smith-Lemli-Opitz syndrome: First reported case and consideration of mechanism, Am J Med Genet C Semin Med Genet, 154C (2010) 142-145.

[19] T.E. Herman, M.J. Siegel, B.C. Lee, S.B. Dowton, Smith-Lemli-Opitz syndrome type II: report of a case with additional radiographic findings, Pediatr Radiol, 23 (1993) 37-40. 
[20] L.P. Singer, R.W. Marion, J.K. Li, Limb deficiency in an infant with Smith-Lemli-Opitz syndrome, Am J Med Genet, 32 (1989) 380-383.

[21] P. Marcorelles, A. Laquerriere, Neuropathology of holoprosencephaly, Am J Med Genet C Semin Med Genet, 154C 109-119.

[22] E. McCann, A.E. Fryer, R. Craigie, C. Baillie, M.E. Ba'ath, A. Selby, L.G. Biesecker, Genitourinary malformations as a feature of the Pallister-Hall syndrome, Clin Dysmorphol, 15 (2006) 75-79.

[23] S. Kang, J.M. Graham, Jr., A.H. Olney, L.G. Biesecker, GLI3 frameshift mutations cause autosomal dominant Pallister-Hall syndrome, Nat Genet, 15 (1997) 266-268.

[24] D. Donnai, J. Burn, H. Hughes, Smith-Lemli-Opitz syndromes: do they include the Pallister-Hall syndrome?, Am J Med Genet, 28 (1987) 741-743.

[25] A. Verloes, Numerical syndromology: a mathematical approach to the nosology of complex phenotypes, Am J Med Genet, 55 (1995) 433-443.

[26] J.G. Hall, P.D. Pallister, S.K. Clarren, J.B. Beckwith, F.W. Wiglesworth, F.C. Fraser, S. Cho, P.J. Benke, S.D. Reed, Congenital hypothalamic hamartoblastoma, hypopituitarism, imperforate anus and postaxial polydactyly--a new syndrome? Part I: clinical, causal, and pathogenetic considerations, Am J Med Genet, 7 (1980) 47-74.

[27] J.A. Porter, K.E. Young, P.A. Beachy, Cholesterol modification of hedgehog signaling proteins in animal development, Science, 274 (1996) 255-259.

[28] R. Maymon, R.F. Ogle, L.S. Chitty, Smith-Lemli-Opitz syndrome presenting with persisting nuchal oedema and non-immune hydrops, Prenat Diagn, 19 (1999) 105-107.

[29] M. Witsch-Baumgartner, B.U. Fitzky, M. Ogorelkova, H.G. Kraft, F.F. Moebius, H. Glossmann, U. Seedorf, G. Gillessen-Kaesbach, G.F. Hoffmann, P. Clayton, R.I. Kelley, G. Utermann, Mutational spectrum in the Delta7-sterol reductase gene and genotype-phenotype correlation in 84 patients with Smith-Lemli-Opitz syndrome, Am J Hum Genet, 66 (2000) 402-412.

[30] M. Witsch-Baumgartner, M. Gruber, H.G. Kraft, M. Rossi, P. Clayton, M. Giros, D. Haas, R.I. Kelley, M. Krajewska-Walasek, G. Utermann, Maternal apo E genotype is a modifier of the SmithLemli-Opitz syndrome, J Med Genet, 41 (2004) 577-584. 
A

1 से 2
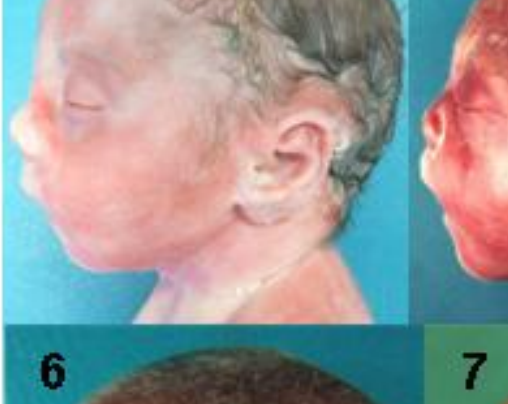

$\infty$

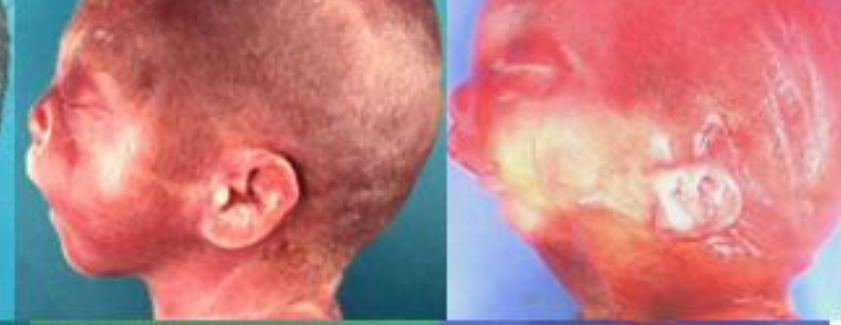

4

5
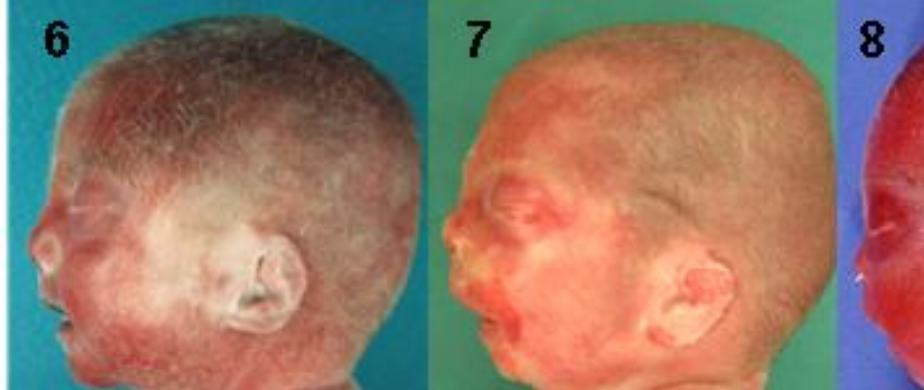

B
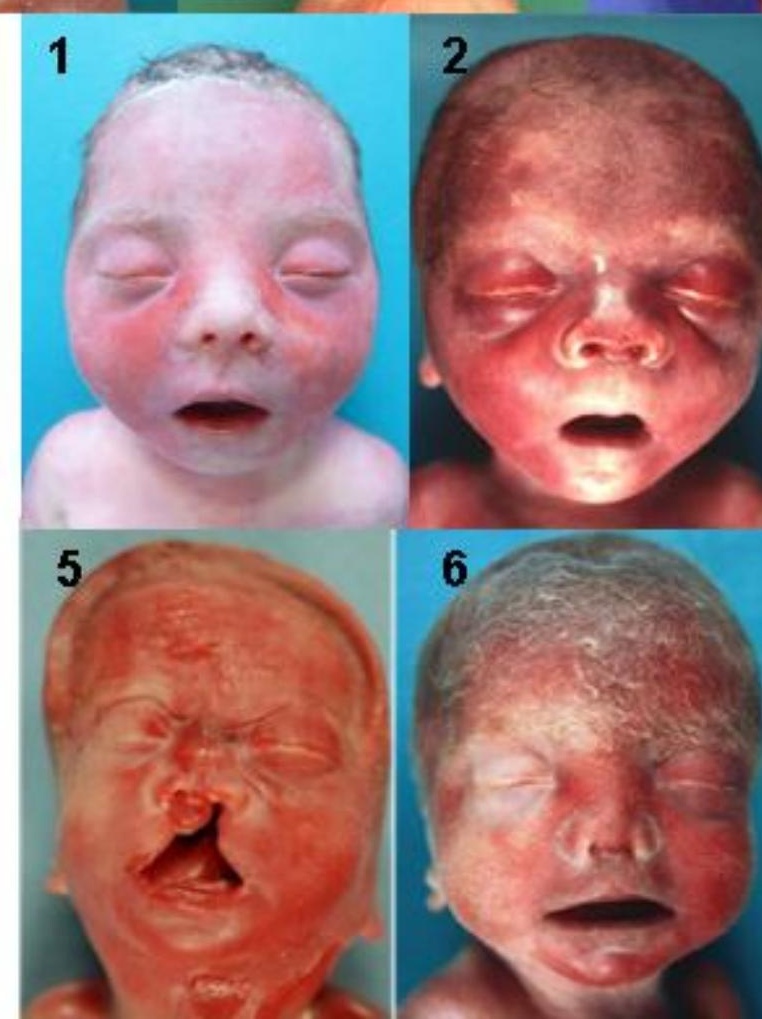

$$
6
$$
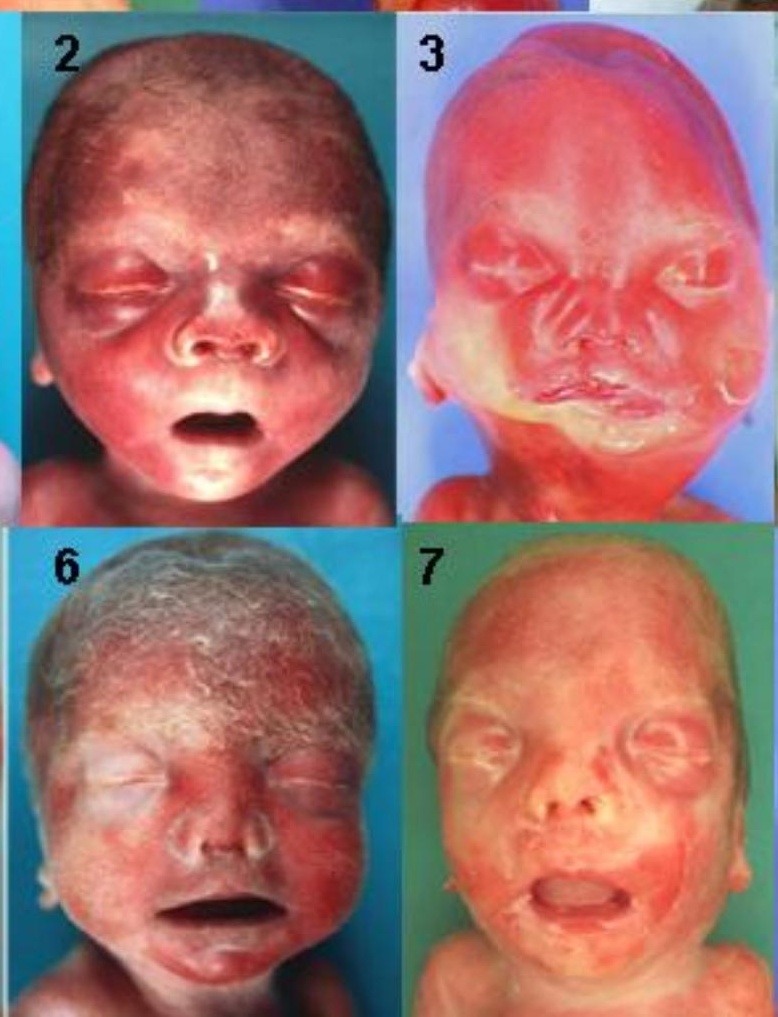

8

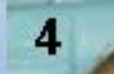

Figure 1

\section{0}
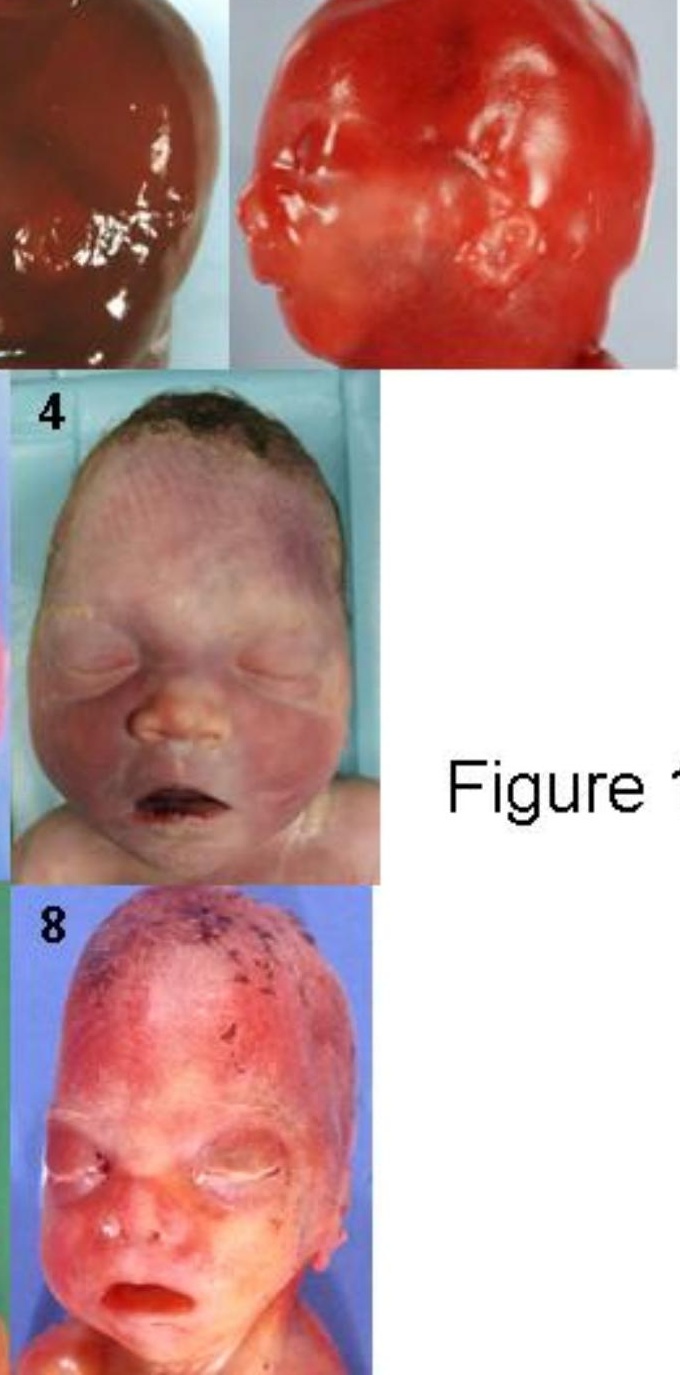


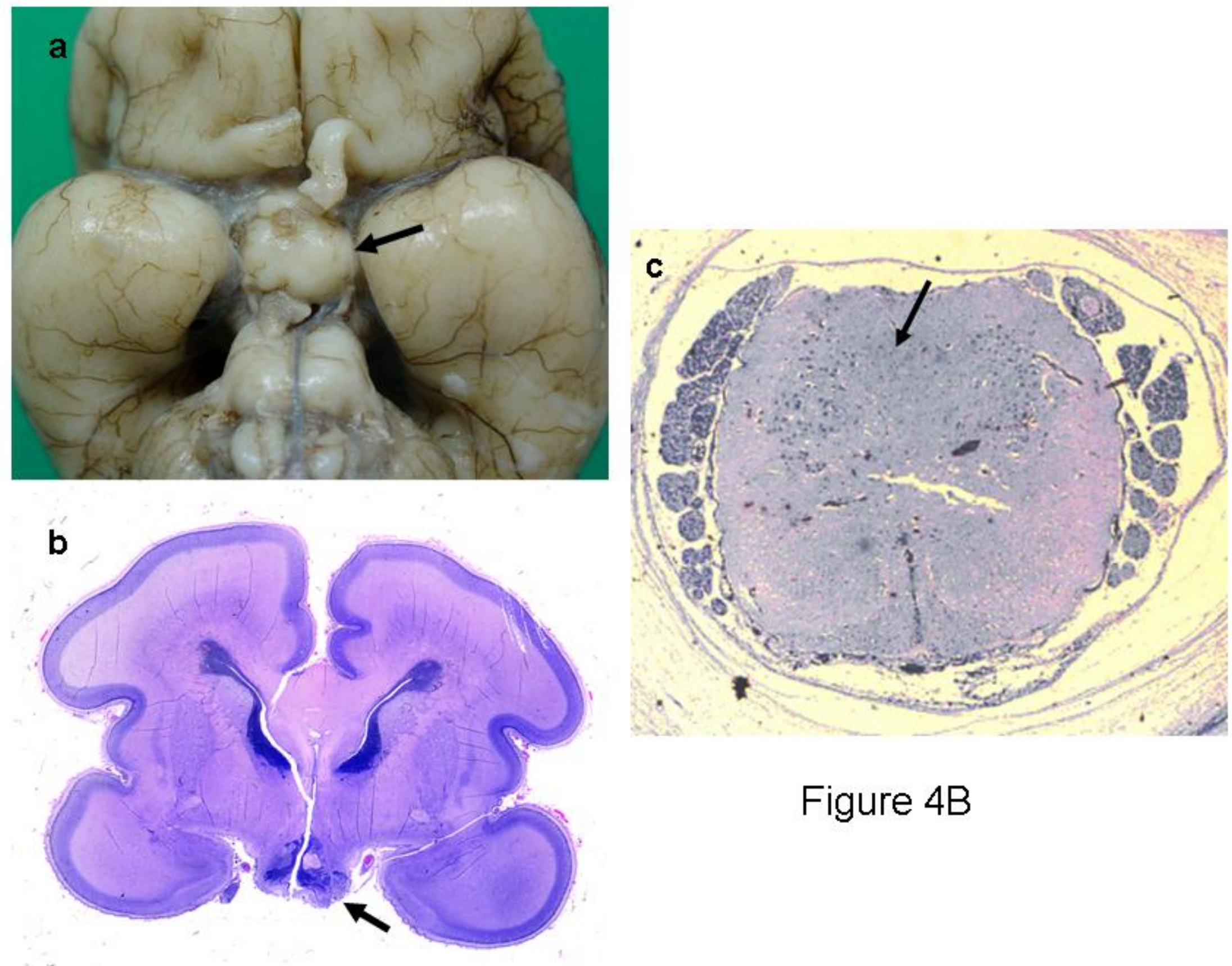

Figure 4B 


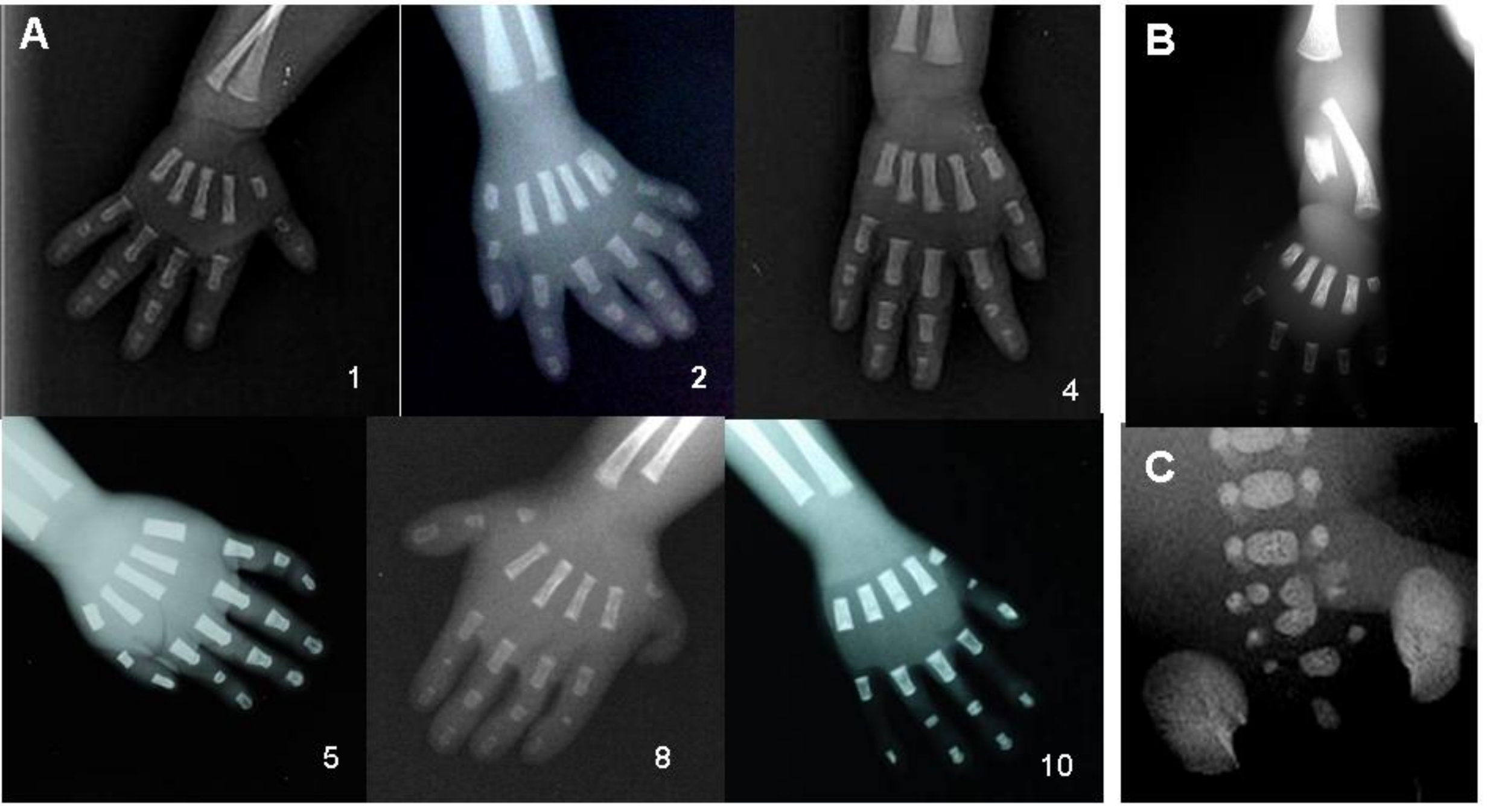

Figure 5 